Check for updates

New York

Cite this as: $B M J 2020 ; 370: \mathrm{m} 3739$ http://dx.doi.org/10.1136/bmj.m3739 Published: 24 September 2020

\title{
Covid-19: CDC publishes then withdraws information on aerosol transmission
}

\section{Janice Hopkins Tanne}

The US Centers for Disease Control and Prevention provoked controversy when it changed information about airborne transmission of covid-19 last week.

On Friday 18 September the CDC posted information on its website that for the first time said covid-19 could be spread through "respiratory droplets or small particles, such as those in aerosols, produced when an infected person coughs, sneezes, sings, talks, or breathes. These particles can be inhaled into the nose, mouth, airways, and lungs and cause infection. This is thought to be the main way the virus spreads."

It added, "There is growing evidence that droplets and airborne particles can remain suspended in the air and be breathed in by others and travel distances beyond 6 feet (for example, during choir practice, in restaurants, or in fitness classes). In general, indoor environments without good ventilation increase this risk."

On Monday 21 September the CDC removed the information about aerosols and distances greater than 6 feet $(1.8 \mathrm{~m})$ and replaced it with previous information that warned only about droplets and advised people to stay 6 feet apart. ${ }^{1}$

The CDC said that a draft version of proposed changes had been posted in error. The agency said it was updating information about airborne transmission of covid-19 and would post the new information once the review was completed.

The suggestion that covid-19 could be spread by aerosols, which can hang in the air for hours and spread over distances, has implications. As colder weather will force people indoors, concerns are rising about increased transmission in enclosed spaces and the efficacy of ventilation.

Scientists had earlier warned about airborne transmission by aerosols.

In April a scientific panel sent a letter to the White House saying that "studies are consistent with aerosolization from normal breathing." ${ }^{2}$

In July two scientists published a commentary in Clinical Infectious Diseases saying it was time "to recognize the potential for airborne spread ... There is significant potential for inhalation exposure to viruses in microscopic respiratory droplets (microdroplets) at short to medium distances (up to several meters, or room scale) and we are advocating for the use of preventive measures." 3

Two other scientists said in the Washington Post that the CDC was wrong and that airborne transmission had been known for months. Joseph Allen from Harvard's school of public health and Linsey Marr from Virginia Tech's engineering department, wrote, "Many scientists have known that airborne transmission of the virus was happening since February. The CDC somehow failed to recognize the accumulating evidence that airborne transmission is important and therefore failed to alert the public ... When you talk or sing-or even just breathe-you emit a range of particles of different sizes.” Some particles are large and fall to the ground within 6 feet, but "there are also thousands of particles that are smaller than five microns. Such particles stay aloft for minutes to hours and can travel all the way across a room on natural air currents."4

Marr later told National Public Radio, "We need to do something beyond 6 feet." She said that meant masks and ventilation and filtration. ${ }^{5}$

The controversy about CDC's conflicting advice came as the US recorded more than 200 ooo deaths from covid-19. President Donald Trump asserted that the virus was mostly defeated and the country should reopen its businesses, factories, and schools.

The CDC has faced several controversies recently. Michael Caputo, a spokesman for CDC's parent agency, the Department of Health and Human Services, took a leave of absence after posting social media messages accusing government scientists of "sedition." Science advisor Paul Alexander, who tried to edit and delay CDC public health reports, has recently left the agency.

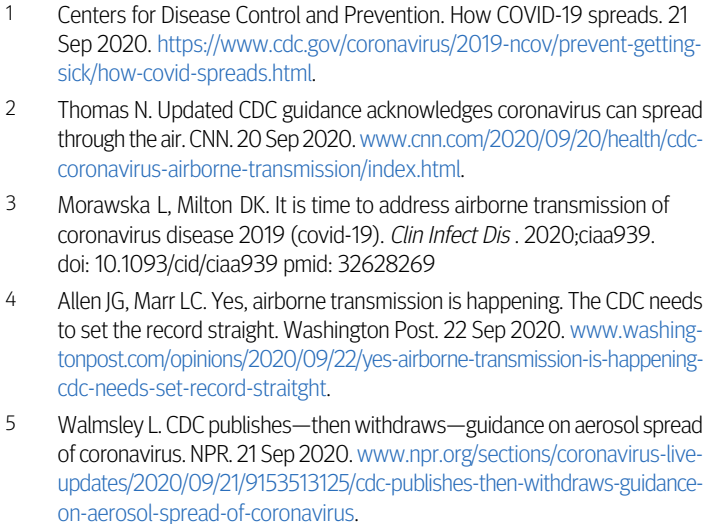

2 Thomas N. Updated CDC guidance acknowledges coronavirus can spread through the air. CNN. 20 Sep 2020. www.cnn.com/2020/09/20/health/cdccoronavirus-airborne-transmission/index.html.

3 Morawska L, Milton DK. It is time to address airborne transmission of coronavirus disease 2019 (covid-19). Clin Infect Dis . 2020;ciaa939. doi: 10.1093/cid/ciaa939 pmid: 32628269

4 Allen JG, Marr LC. Yes, airborne transmission is happening. The CDC needs to set the record straight. Washington Post. 22 Sep 2020. www.washing tonpost.com/opinions/2020/09/22/yes-airborne-transmission-is-happeningcdc-needs-set-record-straitght.

5 Walmsley L. CDC publishes - then withdraws - guidance on aerosol spread of coronavirus. NPR. 21 Sep 2020. www.npr.org/sections/coronavirus-liveupdates/2020/09/21/9153513125/cdc-publishes-then-withdraws-guidanceon-aerosol-spread-of-coronavirus. 